\title{
An authentic assessment model to assess kindergarten students' character
}

\author{
${ }^{* 1}$ Umi Faizah; ${ }^{2}$ Darmiyati Zuchdi; ${ }^{3}$ Yasir Alsamiri \\ ${ }^{1}$ Department of Islamic Early Childhood Education, Sekolah Tinggi Pendidikan Islam Bina Insan \\ Mulia Yogyakarta \\ Jl. Jembatan Merah No. 116K, Prayan, Depok, Sleman, Yogyakarta 55283, Indonesia \\ ${ }^{2}$ Department of Social Sciences Education, Universitas Negeri Yogyakarta \\ Jl. Colombo No. 1, Karangmalang, Depok, Sleman, Yogyakarta 55281, Indonesia \\ ${ }^{3}$ College of Education, University of Hail \\ P.O. Box 2440, Hail, 81481, Kingdom of Saudi Arabia \\ *Corresponding Author. E-mail: umifaizah74@gmail.com
}

Submitted: 25 April 2019 | Revised: 19 August 2019 | Accepted: 3 September 2019

\begin{abstract}
The aim of character development is essential to know, especially for kindergarten pupils. It might help teachers in developing students and offering helps and services. Thus, an assessment model is needed to identify children's character development easily and accurately. This study aims to (1) develop an assessment model for evaluating kindergarten pupils' character which is considered valid, reliable, and fulfill the criteria of goodness of fit statistic, and (2) know the characteristics of an authentic assessment model instrument to assess the achievements of early childhood characters in kindergarten. This research used Plomp's Research and Development Model. Data were collected using a questionnaire, documentation, interview, observation, and Focus Group Discussion. The validation was proven by the expert judgment with the Aiken's V formula and the reliability was estimated with Cronbach's Alpha. The validation construct and reliability were examined using Exploratory Factor Analysis, followed by Confirmatory Factor Analysis to ensure the result. Furthermore, the results of this research show that (1) the assessment model developed is ASOKA. This model is considered valid and reliable as it meets the criteria of goodness and fits the statistic; (2) the characteristics of an authentic assessment model instrument to assess the achievements of early childhood characters in kindergarten are: (a) with the index of Aiken's V analysis results of 0.901 , the content validity is considered high; (b) the instrument construct validity has fulfilled the criteria of goodness of fit statistic; (c) as seen from Alpha Cronbach value coefficient 0.914 , its instrument reliability is considered good enough.
\end{abstract}

Keywords: ASOKA model, authentic assessment, pre-school student

Permalink/DOI: https://doi.org/10.21831/reid.v5i2.24588

\section{Introduction}

Education in Indonesia is still encountering an unfavorable situation, particularly when it is being related to the low quality of the educational process and outcomes as well as the nation's weak characters (Abidin, 2012). Many issues reflect weak characters, one of which is the brawl among students which is unexpectedly worrying. Another worse example is the nglithib (viciously hurting someone by using sharp things) which may cause death. Those various conflicts arising today are not only triggered by the economic crisis, but also by the moral crisis. Given these circumstances, the educational institution is the first institution to be questioned. One of the reasons that can be put forward is that educational institutions are the most effective means of strengthening the character of the nation. Besides, the character is also a bench- 
mark of educational success. Based on the historical research of all countries in the world, education has two main purposes: to guide young people to be intelligent and to have virtuous behavior (Lickona, 1991, p. 5). The educational purposes are not limited solely to intelligence. Character is another important purpose of education. The existing education is supposed to be able to create highly intelligent students with the best character.

In addition, education is again the most essential aspect of the quality improvement of Indonesian people. Referring to its basic role, education is a path of human quality improvement that emphasizes the formation of basic quality, such as faith, piety, personality, intelligence, and so forth (Naim, 2012, p. 25). On the other hand, education has a very strategic value in improving the quality of the nation. Thus, breakthroughs to develop the character of the nation through character education programs need to be reformulated.

As might have known, character education is not a new thing in the national education system, since the objectives of the national education, as stated in all laws, substantively contain character education, despite the different formulas. The characters which are developed within the system are not just a horizontal relationship between individuals with other individuals, yet it also deals with the vertical relationships between individuals and Allah Swt. In this case, faith becomes the core of a man while he is controlled by his belief/faith (Majid \& Andayani, 2011, p. 65). Thus, in Islamic educational institutions, faith becomes the target of education. Similarly, in the formulated character education references, religious values become the main target that must be developed for each learner. Conceptual character education manuscripts have been designed in such a way to produce the character of human beings. It is reflected in the 2005-2025 National Long-Term Development Plan which places character education as the first mission to realize the vision of national development. Hence, character building is meant to make particular groups realize the well-mannered society with noble characters.

Concerning the effort to realize character education as mandated in the National
Long-Term Development Plan, the character building has been stipulated in the function and objectives of national education, as in the Law of Republic of Indonesia No. 20 of 2003 on National Education System. Thus, the National Long-Term Development Plan and the Law on National Education System are solid foundations for implementing the operation of cultural education and nation character as the priority program of National Education Ministry 2010-2014, as outlined in the National Character Education Action Plan.

Based on the data obtained on implementation of the character education in Kindergarten or Raudhatul Athfal, character education had not been implemented optimally. It is in line with the findings of Zuchdi (2006, pp. 92-93) which concluded that the context of school education has not fully supported the implementation of character education, especially the achievement in implementing character education at the kindergarten level, and only four skills were managed to be developed, namely greeting, being friendly, helping others, and asking for help politely. In achieving the mission of developing people's characters, each related institution, starting from families, educational institutions, and communities should take their roles based on their own capacities. Concerning character development in kindergartens as the initial formal education, schools and teachers attempt to integrate values in the character education through lessons and school environment, and there should be assessment systems that can monitor the character development of early learners in kindergartens.

The learners' cognitive development has been the focus of almost all teaching strategies. In this context, it is not easy to develop the affective and psychomotor aspects of learning (Suyadi, 2013, p. 189). The affective learning strategy will be useful to improve learners' attitudes during learning activities (Hamruni, 2009, p. 20). It is developed based on the behavioral psychology with stimulusresponse (s-r) concept to form new behavior (attitude). Thus, the affective strategy aims to develop values in character education. In other words, the affective aspect will strongly influence the learners' feelings or positive 
emotions, so teachers will view the learning as 'a process to become' rather than 'the results' (Suyadi, 2013, p. 190). Thus, an assessment model that can be used to track the character building in a learning process is needed. To serve the purpose, the authentic assessment is the best assessment that can be used.

The authentic assessment is based on the real-life context and requires multiple approaches to solve a problem. This assessment involves performance measurement which reflects the learners' competencies as observed in their learning, achievement, motivation, and attitude (O’Malley \& Pierce, 1996, p. 4). The competencies to achieve are attitude, knowledge, and skill, based on the recommended national standards (Law of Republic of Indonesia No. 20 of 2003 section 35 verse 1). In other words, this type of assessment monitors and measures learners' competencies in multiple problem-solving situations in a real-life context. It is expected that this authentic assessment model can be a solution to provide an excellent assessing system and the instruments can be easily used by teachers and accurately measure learners' performance in kindergartens (Taman Kanak-Kanak or TK) and Raudlatul Athfal (RA).

During the preliminary study, a survey and interview were conducted to 21 participants from $T K$ and $R A$ principals and teachers from June to September 2014 in several kindergartens in Sleman regency, Yogyakarta. The result shows that $70 \%$ of teachers had not implemented a proper assessment of learners' learning, $40 \%$ of teachers revealed that they regarded the assessment only as burdensome administrative duties, and $80 \%$ of teachers and $T K$ and $R A$ did not have proper assessment instruments. The assessment in character education should be carried out integratedly and continuously, that is by observation, task completion, conversation, and task submission to provide a conclusion for the achievement of indicators for character values. The preliminary study also revealed that the majority $(65 \%)$ of $T K / R A$ teachers determined the level of children's character achievement based on the teachers' personal perception, knowledge, and interpretation, and not based on daily recorded data. It then resulted in the teachers' unawareness in learning the achievement level of children's character development confidently; particularly on whether it has developed optimally or not.

Besides, it can be seen that although character values have been integrated into the daily activity plans, teachers remain depicting hesitance in determining the decision on the achievement level of children's character development because the indicators employed in the children's character development assessment tend to be too broad and not specified in details. Thus, it is necessary to have an assessment model that can be applied specifically to identify children's character development easily and accurately, so that teachers can provide assistance and service to students to develop their potentials and characters according to each child's developmental needs. With appropriate assessment options, teachers will be able to detect each child's developmental achievements appropriately.

Based on those descriptions, the model developed in this study is an authentic assessment model to assess the character achievement level, including: (1) the theoretical formation of TK/RA children's character dimensions in the construct of the assessment model; (2) the development of an authentic assessment model instruments from the construct of an authentic character assessment model.

\section{Authentic Assessment in Early Childhood Learning in $T K / R A$}

Early age children, including those in $T K$ and $R A$, are in the period of growth and development. Early childhood comprises of various activities of motions, games, and habituations. Thus, the assessment of early age children is done by observing their growth and developmental stages, then comparing them with the indicators. Previous studies (Edgington, 2004, p. 149; Suyanto, 2005, p. 194) state that an assessment of early age and kindergarten children is a process of observing, recording, and documenting the children's performance and work Jamaris, 2004, p. 119), skills attitudes, and performance.

An early childhood assessment aims not necessarily at measuring the achievement and achieving scholastic success, but rather ob- 
serving the level of the developmental progress and abilities that children have made in their various actions, attitudes, performance, and appearance. Thus, assessing early age children's characters in kindergartens does not serve as a purpose to compare the children, but to see and comprehend the development of one child and the other. Jamaris (2004, p. 134) suggests that an observation must focus on the child's behaviors which are then compared with their age. The assessment should be sustainable and holistic, authentic, individual, natural, multi-sources, and multi-context (Suyanto, 2005, pp. 195-196). The use of authentic assessment to measure character can be done by observing children's performances and comparing them with the children's developmental level during the observation. To gain accurate data on children's development, the observation may be done in a school setting during in- or out-class activities.

Assessment of early childhood is conducted in an authentic manner with real, functional, and natural activities (Suyanto, 2005, p. 196). It is done to get an overview of the real development of children's abilities, by presenting valid and comprehensive data through record-keeping of children's creativity in detail about their strengths and weaknesses, as well as significant events in their lives (Edgington, 2004, p. 147; Jamaris, 2004, p. 119).

An authentic assessment in learning is a process or formal effort to collect information on the important variables of learning as evaluation materials and decision making by teachers to improve the process and students' learning outcomes (Herman, Aschbacher, \& Winters, 1992, p. 95; Popham, 1995, p. 5). In this description, it is understood that an authentic assessment involves learners in purposeful and meaningful authentic assessment.

The term 'authentic assessment' was first introduced by Wiggins in 1988 in the journal Pbi Delta Kappa entitled 'Authentic Assessment' (Zaenul, 2001, p. 4). The assessment is also known as an alternative assessment, in contrast with its more widely known traditional counterpart of the traditional assessment in the form of a paper and pencil test. Due to this case, the idea of the alternative assessment raises more serious attention and becomes the turning point of the widespread discussion of authentic assessment.

An authentic assessment is considered as an effort to integrate the learning achievement measurement with the overall learning process. It must be noted that the assessment itself is a part of the learning process as a whole. Therefore, TK/RA teachers should learn about the purpose of the authentic assessment and be able to apply it in the learning process to make it more effective.

Sometimes, the term 'authentic assessment' is interchangeable with other terms. That is an alternative assessment referring to the process of assessing students' behavior performance on a multidimensional basis in real situations. In other words, alternative assessment can be defined by using nontraditional approaches to measure students' performances and learning outcomes.

An authentic assessment typically involves a task for learners to display and assessment criteria or a rubric to assess the task performance. Arends (1997, p. 284) defines an authentic assessment as a process to assess students' performance in carrying out certain tasks in real situations.

From those statements, it is concluded that the assessment to assess young learners' characters in TK/RA is categorized as an authentic and classroom-based assessment. A classroom-based assessment will be able to reveal the learners' real conditions in the classroom (Stiggins, 1991, p. 8). This authentic and classroom-based model is appropriate for assessing the child's character achievement consisting of 14 characters. An authentic assessment is a comprehensive assessment process (encompassing all aspects of learning), continuous and inseparable from the learning process, aiming to determine the progress and achievement of students and to improve the planning, process, and learning achievement.

\section{Character Values Developed in $T K / R A$}

The character values developed in TK/ RA are based on the opinions of experts (BarOn, 2000, 2005; Gardner, 1996; Thorndike, Hagen, \& Sattler, 1986). Further, through the FGD consisting of two experts in character education and five other experts, three aspects 
were selected, namely spiritual, personal, and social aspects. In the development of character values which had been validated by expert judgment, the three aspects were developed into 14 characters values: faithful, worshipping ritual, humane, honest, patient and modest, brave and confident, disciplined, creative, independent, caring/empathy, tolerant, cooperative, and polite and humble. Each of these characters is explained as follows.

\section{Faithful}

Being faithful is the first character instilled in every Muslim child. It can be seen from the way Muslims welcoming their newborn by reciting adzan in the baby's right ear and iqomah in the left ear. It is evidence that the first and foremost value developed by Muslims is believing in God (Allah) (Marzuki, 2015 , p. 32). Being faithful in this context is linked with rukun iman (the pillars of faith).

\section{Worshipping Ritual (Hablun minallah)}

Worshipping ritual is a part of sharia (Islamic law). The Prophet Muhammad Saw. taught that after taubid (believing that Allah is the One and Only God) comes sharia in the form of worship and muammalah (humanity) (Marzuki, 2015, p. 45). Worshipping can be defined as rules regulating the direct relationship (ritual) between human beings and Allah (Ash-Shiddieqy, 2009). In other words, the character-building through worshipping rituals is simplified by implementing six pillars of faith and five pillars of Islam.

In this study, the discussion of worship and muamalah are separated into the character values that must be instilled in students of $T K / R A$. Based on Islamic teaching, everything conducted by Muslims can all be counted as worship, when it is intended as a form of devotion to Allah Swt. Thus, the term worshipping ritual is used. Worshipping ritual is associated with the implementation of the Five Pillars (rukun Islam).

\section{Humanity (Hablum minannas)}

The Islamic character is divided into two parts: the character of Khalik (Allah Swt.) and the character of beings (other than Allah) (Marzuki, 2015, p. 32). The character of be- ings can be broken down into several types, one of which is the character of fellow humans (bablun minannas).

Muamalah means treatment or action towards others, the relationship of interests (Munawwir, 1997), and muamalah means action between humans and other than humans. The actual activity is difficult to distinguish from the character of the social aspect, but in this study, performing muamalah (bablun minannas) is doing an activity which have something to do with other people is related to behavior in Islamic teachings, namely, those contained in the Qur'an and/ or al-hadits.

\section{Honesty}

Honesty literally means straight heart, not lying, not cheating. Honesty is an important value that must be owned by everyone. Honesty is not only shown verbally, but it is reflected in everyday behavior (Naim, 2012 , p. 132). Honest character must be instilled from an early age by using various approaches and setting exemplary behaviors.

\section{Patience and Modesty}

Being patient means being able to refrain from anger. Patience is a positive character that must be instilled in children early on. It is the ability to control oneself. Armed with patience, a child will be able to resist the inner impulse and think before acting. It will guide the child to do the right things and less likely to take actions ending in bad results (Naim, 2012, p. 56). By instilling patience, it is expected that children will be able to wait patiently without easily getting upset, and they are willing to wait their turn orderly (queuing).

Modesty is a way of life that is not excessive. Modesty is the inner attitude of a person who fully believes that God enlarges the sustenance of his servants, so he becomes a servant of God who is impervious and satisfied with what has been earned so far (Munawar-Rachman, 2015, p. 373).

\section{Bravery and Confidence}

Being brave and confident are important characters that should be instilled early on. Being courageous is often associated with self-confidence because it is believed that 
courage grows from a positive self-image. A child with a positive self-image will be courageous to try tackling difficult things or challenges. The child has the confidence that he is able and, therefore, he is willing to try. Confidence is an attitude of believing in one's ability (self-ability). Confidence removes worry in conducting one's action. Confidence fosters a sense of freedom to do as he desires and at the same time fosters a sense of responsibility for his actions. It also fosters a sense of achievement and fosters the ability to recognize the advantages and disadvantages of oneself. Louster (2002, p. 4) describes a person with self-esteem as a selfless person who does not need the encouragement of others, always being optimistic, and happy. According to Schiller and Bryant (2012, pp. 76-77), self-confidence is someone's ability to weigh choices and make the decision to choose one choice freely and consciously.

\section{Self-Discipline}

Self-discipline is shown when students respect and do a system requiring people to obey provisions, orders, and regulations in pursuance. In other words, self-discipline is an attitude of obeying established regulations and provisions without any intention/expectation of rewards (Naim, 2012, pp. 142-143).

Self-discipline is an intended influence to help children deal with their environment. Self-discipline is developed from the need to maintain the stabilization between individuals' tendencies and intentions to achieve their goals in regard to environmental expectations (Semiawan, 2008, pp. 27-28). Self-discipline stated in this study is children's willingness to correctly adhere to the rules.

\section{Creativity}

Creativity is one of the most essential character values. By possessing creative character, a child may experience a dynamic life. His mind is constantly developed and he constantly conducts activities to explore valuable things (Naim, 2012, p. 152). Creativity is an attitude and action reflected in innovation in many aspects of problem-solving. Thus, a creative person can always find better new ways with diverse results compared to the previous ones (Suyadi, 2013, p. 8). Creativity becomes an essential character for early-aged children.

\section{Self-Independence}

Self-independence is the ability to be independent without relying on other people (Marzuki, 2015, p. 98). It is an essential character that needs to be instilled from an early age. By instilling a sense of independence, it is hoped that children will be initiated in doing things they should be able to do by themselves. As a result, they will be skillful in life.

\section{Caring/Empatby}

Caring is an attitude that shows tendencies on problems, situations, and conditions occuring in the children's surroundings by being involved in them. Being emphatic is reflected in the way children intend to be treated. It is in line with Schopenhauer (1997, p. 190) who states that caring is based on a principle: "Treat others the way you want to be treated'. Children who care are those who move to do something to inspire, change, and do good deeds to surroundings. Caring usually comes from loving. To develop a sense of caring, as in other moral values, learning involving approaches of developing three characters aspects i.e. knowing, feeling, and acting needs to be done (Lickona, 1991, p. 312).

\section{Tolerance}

Tolerance is one of the essential characters to be instilled from an early age. By instilling tolerance at an early age, children are expected to accept diversity and believe that God creates a variety of humans with various perfections and lacks. Tolerance is a permissive attitude toward disagreement or the ability to consider different opinions, attitudes, or ways of life (Naim, 2012, p. 138). The development of tolerance is due to willingness and awareness to respect differences.

\section{Responsibility}

Responsibility is the main essential character which need to be instilled at an early age. The concept of responsibility in this stud$y$ is the effort performed when completing tasks. The tasks should be done at best, and anybody performs the effort should take any 
possible risk. Moreover, he should be able to solve any problem. In the literal meaning, it is the ability to respond to something. A peopleoriented attitude is implied in the definition, and it shows the attitude of actively responding to other's needs (Lickona, 2004, p. 44).

Responsibility is defined by maximizing one's capabilities in an attempt of doing something (Munawar-Rachman, 2015, p. 345). With the responsibility character, it is expected that children can maximize their effort in doing their tasks.

\section{Cooperation}

Cooperation stated in this research includes mutual cooperation and active participation in a work assigned in groups. The sense of cooperation is shown in how children do group tasks well, help others who have not finished their tasks, and ask others to play around together. Cooperation is developed by the principle of mutual respect and affection. Cooperations also mean helping each other in kindness and devotion as suggested by Islamic provisions: ta'awun 'ala al birr wa al taqwa (Munawar-Rachman, 2015, p. 259).

\section{Politeness and Humbleness}

Politeness and humbleness are in one of the main characters that should be instilled in early childhood. The concepts of politeness and humbleness stated in this paper include the character of prioritizing values in behaving and respecting others in the ways children speak and act (Miskawaih, 1994, p. 81).

Humbleness teaches children to take others' knowledge, strength, and other qualities into account. Humbleness is politeness and not arrogant (Munawar-Rachman, 2015, p. 230). Human glory is measured by the quality of their humbleness in life.

\section{Method}

This research and development employ a set of stages suggested by Plomp (1997, p. 5) covering five stages: (1) the preliminary investigational phase, (2) the design phase, (3) the realization/construction phase, (4) the test, evaluation, and revision phase, and (5) the implementation phase. There are two main stages in this research: the research/ pre-research stage and the development stage. The pre-research activities include investigation, design, and construction, while the development stage covers the activities of testing, evaluating, and revising. The R\&D model by Plomp includes five stages: preliminary investigation, assessment model planning, and designing, assessment instrument development, assessing, assessment of evaluation items, item assessment, and assessment implementation. The development procedure of ASOKA (Authentic Character Assessment) can be seen in Figure 1.

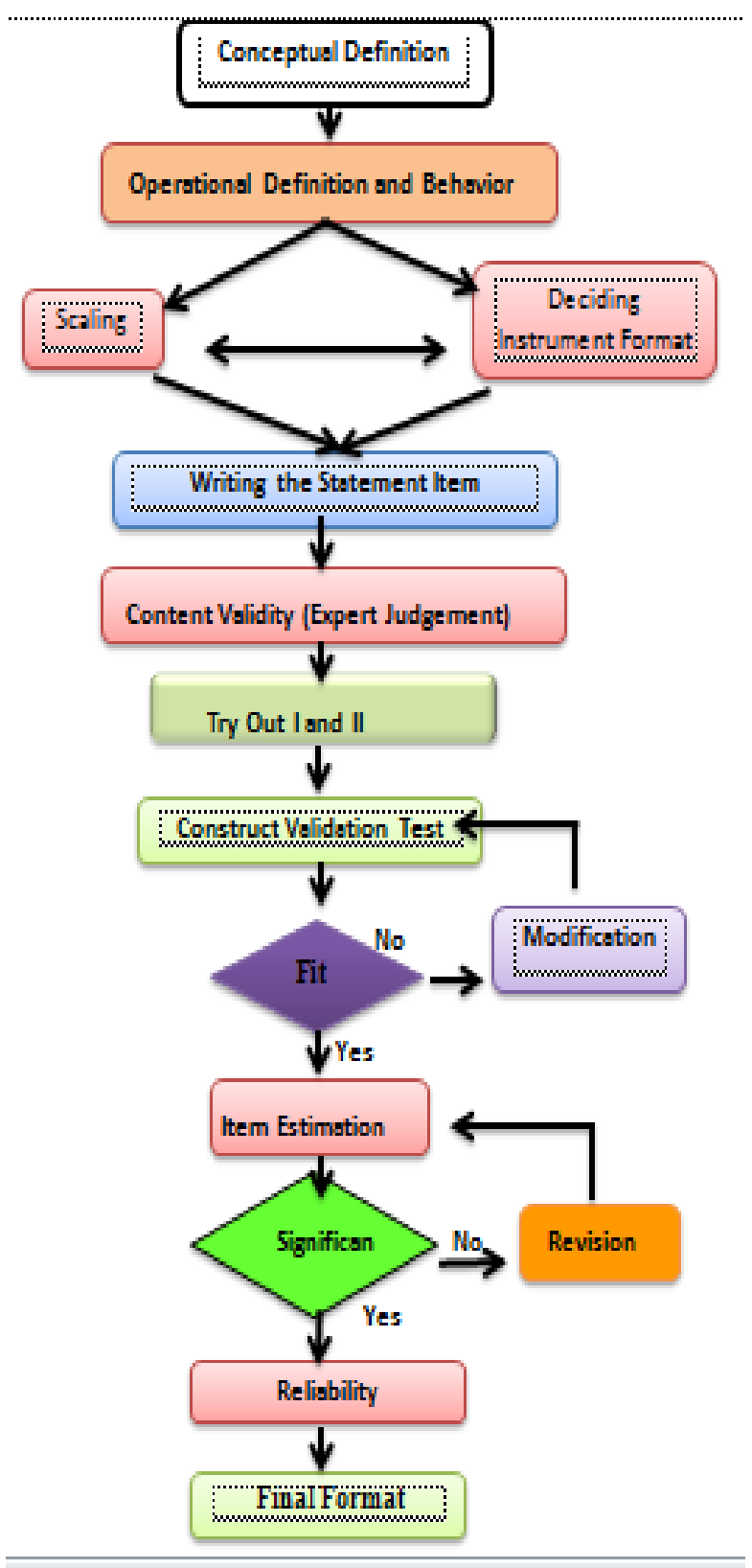

Figure 1. Development procedure of ASOKA measure 


\section{Findings and Discussion}

Findings

\section{The Theoretical Validation Result of ASOKA Model}

In the evaluation phase of the first model of ASOKA, to prove the validity, the content of the instrument was analyzed by the experts which consist of assessment experts, character education experts, $P A U D / T K / R A$ experts, and Islamic Education experts to gather the expert judgment. The experts on children's development psychology were not included in this phase since the researchers consider the assumption that they are represented by the experts on $P A U D / T K / R A$. The readability test was administered to teachers of $T K / R A$ and some $T K / R A$ principals.

The validation test was done to know whether the assessment measure could measure the early age children's character development, especially those in $T K / R A$ level. The explanation of the product evaluations from expert judgment is described as follows.

Content Validity in the ASOKA Model from Experts

The first product validation of the ASOKA model was carried out through expert judgment using the Delphi technique. Validation is intended to make sure that the developed ASOKA model instruments can be used to detect the attainment level of TK/RA children. This Delphi technique was chosen with considerations easier to do, more indepth input, and focused on the problem under study.

Content validation analysis from experts/experts is done by using the formula of Aiken's V. The results of the analysis show that the ASOKA instrument has a good representation related to the accuracy of the indicators of the aspects and accuracy of the items on the indicator. For the criteria for the accuracy of indicators on the aspects assessed, the Aiken validity index identifies that there is 1 (one) indicator that has a lower index than the other indicators $(<0.76)$, while the accuracy of the items on the indicator, the Aiken validity index identifies six items, namely items 1, 2, 3, 4, 10 and 22, have lower indices than other items $(<0.76)$. The six items were then annulled and replaced with new items after a long discussion with SMEs. Furthermore, the new items were reassessed by the SMEs and the content validity index value $(\mathrm{V})$ $\geq 0.76$ was obtained, so it can be concluded that all the items in the ASOKA instrument which amounted to 65 items met the content validity.

The results of the discussion and input from experts, as well as the final index obtained, were then consulted with the promoter and co-promoter. Some changes after consultation with experts through the Delphi method are as follows. (1) Changes to the spiritual aspect, initially consisting of three indicators, namely faith, worship, and honesty, then changed places and new characters emerged, namely, the changes were perfected into faith, worship ritual (bablun minallah), and performing muamalab (bablun minannas), the addition of indicators on the spiritual aspect in the form of muamalah, actually will be a little confusing with the social aspects, but in muamalah, these special indicators are made that are different from the social aspects. (2) Changes in indicators consist of adding, combining, adding a lot given to the character of the faith by including six pillars of faith as a whole, the addition of indicators is also on creative characters, who previously could only use three indicators, into five indicators. (3) Amendment to the number of item statements, previously 56 items, after summarizing all entries from the seven experts to 65 items. (4) Changes to the choice of terms of achievement of child characters, previously with the term Not Developing (Belum Berkembang or BB), Starting to Grow (Mulai Berkembang or MB), Developing Expectations (Berkembang Sesuai Harapan or BSH), and Developing Very Good (Berkembang Sangat Baik or BSB), changing to Unappeared (Belum Muncul or BM), Appearing with Stimulation (Muncul dengan Stimulus or MS), Emerging Not Consistent (Muncul Belum Konsisten or MBK), and Emerging Consistently (Muncul Konsisten or MK).

The full explanation of the three aspects of the character developed is as follows: (1) spiritual aspects, including the character of 
faith, ritual worship (bablun minallah) and muamalab (bablun minannas). (2) Personal aspects, including honest, patient and simplicity, brave and confident, disciplined, creative, and independent. (3) Social aspects, including care/patience, tolerance, responsibility, cooperation, courtesy, and humility.

\section{$\underline{\text { Readability Test Results by Practitioners }}$}

The readability test of the ASOKA instrument aims to ensure (1) the clarity of clues, the scope of ASOKA components, the language used, and the writing procedure and appearance of the assessment in general from the instrument, as a whole are understood by prospective users, (2) the clarity of aspects of character, (3) the clarity of character indicators, (4) the formulation of communicative statements, (5) the use of easily understood sentences and words, (6) the clarity of assessment rubrics, and (7) the written procedures related to letter form, font size, format or instrument layout.

This readability test activity involves practitioners from the elements associated with prospective users, namely teachers, heads of TK/RA, assessment of readability using a modified Likert scale with four choices, namely a minimum score of 1 (cannot be used), score 2 (can be used with little improvement), score 3 (can be used without improvement, and score 4 (ideal used). When consulted with the guidelines the feasibility categorization of the model is included in either classification or it gives an indication that the level of readability of this developed instrument can be classified as good or feasible to use.

\section{Results of ASOKA Model Try-Out I}

Try-Out I involves 106 learners of group B from six TK/RA in Yogyakarta, including: RA DWP UIN Sunan Kalijaga, RA Nurul Dzikri, TK Islam Tunas Melati, TK Aisyiyah Bustanul Athfal Taruna Alquran, RA Masyitoh Ngeposari Gunung Kidul, TKIP Salsabila Pandowoharjo-Sleman. The sample of the limited test is determined by proportional random sampling. The results of the first try-out of the ASOKA model are explained as follows.

\section{Spiritual Aspects}

The achievement of the spiritual aspect of TK/RA is represented by three TK/RA with different characteristics, namely RA Nurul Dzikri (RA-ND), TK Islam Tunas Melati (TK-TM), TK Plus (full day) Salsabila (TKP-SB). The distribution of assessment results on the achievement of children's character in the three institutions RA-ND, TK-TM, and TKP-SB as a representation of TK/RA in Islamic education institutions can be seen in the histogram in Figure 2.

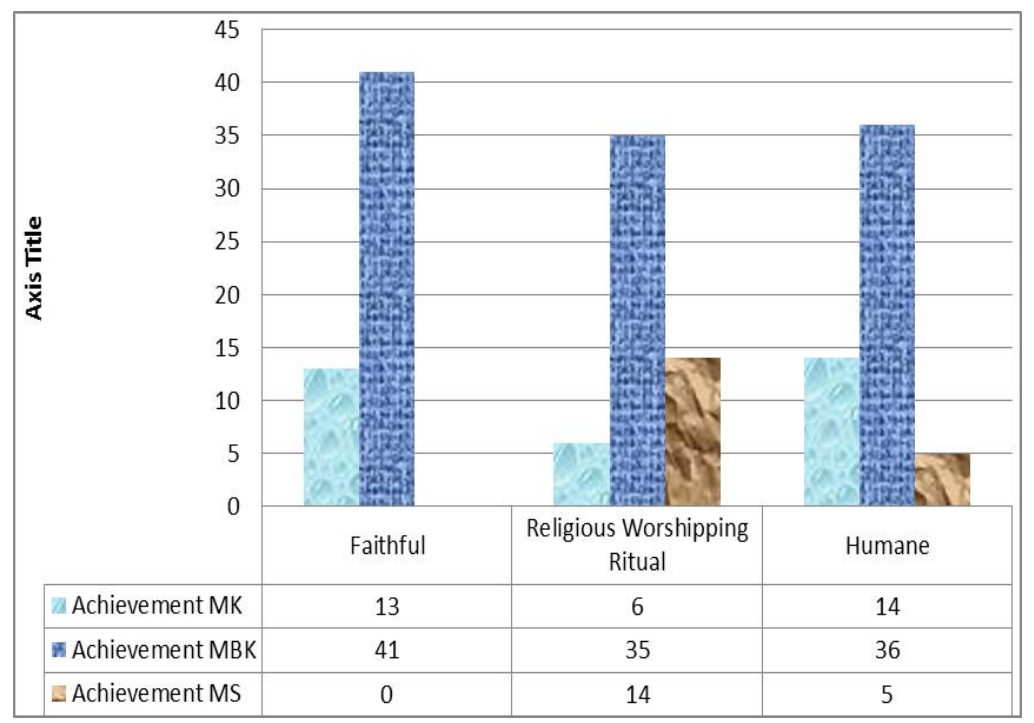

Figure 2. Histogram of distribution of assessment of spiritual character achievement for each component 
In Figure 2, it can be seen clearly that the average achievement of the children's character in the spiritual aspect is dominated by the achievement of MBK (appearing inconsistent), which is $65 \%-75 \%$, whereas the attainment of the MK (consistent emergence) /culture is only about $10 \%$. It proves that the spirituality of the child is still in the developing stage and its appearance has not been consistent, for this reason, it needs to be continually improved with various strategies to instill it into the main character possessed by each student.

\section{$\underline{\text { Personal Aspects }}$}

The assessment results for the achievement of the children's character on the personal aspects can be seen in the distribution in Figure 3. In Figure 3, it can be seen clearly that the average achievement of the children's character in this personal aspect is dominated by the achievement of MBK (Muncul Belum Konsisten or Emerging Inconsistently), which is $75 \%$, while the lowest in the MK (Muncul Konsisten or Consistent Appearance)/creative character is only around $4 \%$, while the highest achievement is independent character, which reaches $45 \%$. It is a challenge for teachers to grow the creative character of each student through a variety of planned stimulation in learning.

\section{$\underline{\text { Social Aspects }}$}

The assessment results for the achievement of the children's character on the social aspects can be seen in the distribution in Figure 4.

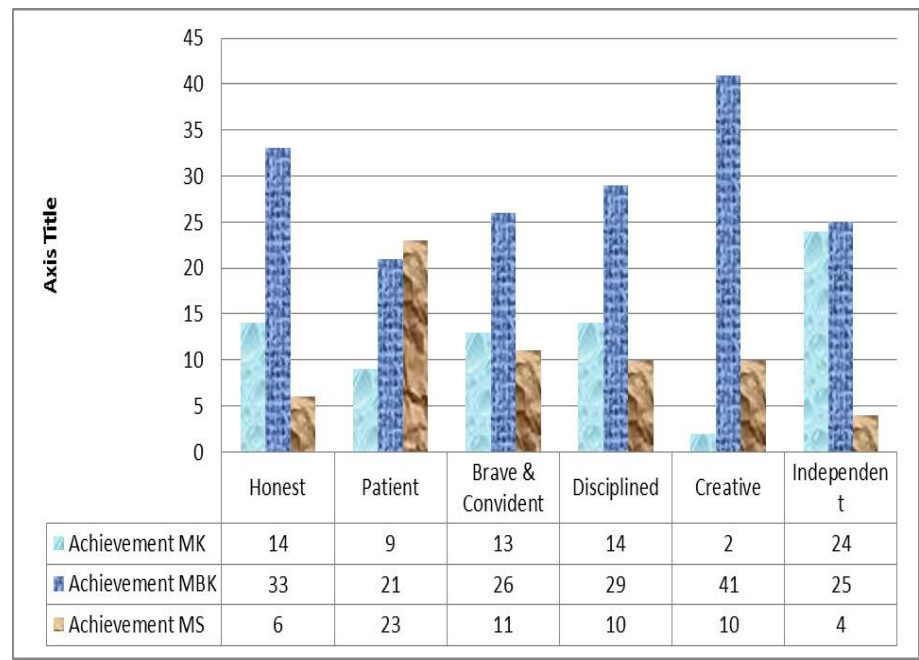

Figure 3. Histogram of personal character aspect achievement for each component

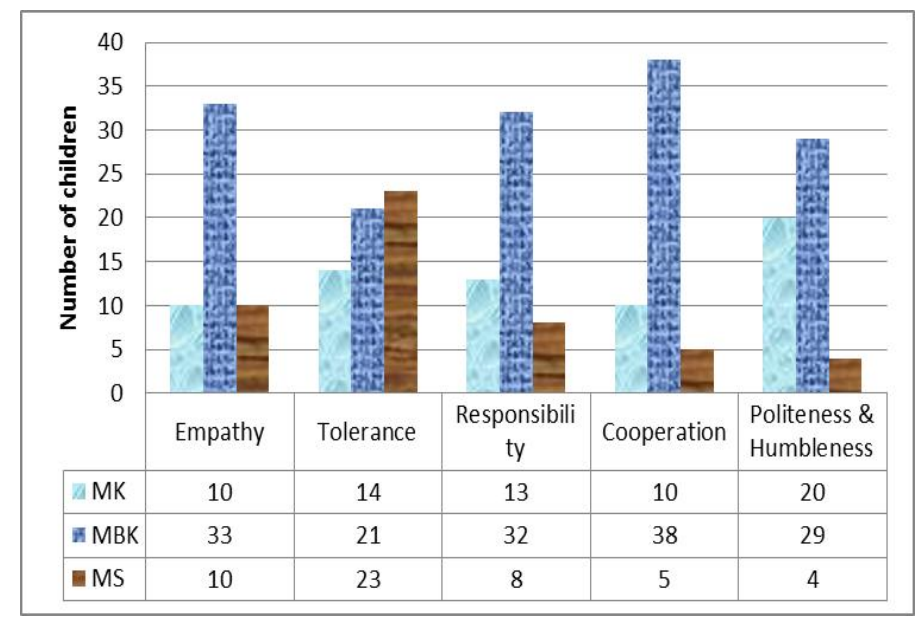

Figure 4. Histogram of distribution of assessment results achievement of child characters on social aspects 
Results of Analysis of Validity and Reliability of ASOKA Instruments

Contract validity testing is a test of validity related to the level of the scale that reflects and acts as a concept being measured (Hair, Black, Babin, \& Anderson, 2010, p. $710)$. Analysis of construct validity on character dimensions was carried out using Explanatory Factor Analysis (EFA) analysis. This analysis serves as a pointer to factors that can explain the correlation between variables.

Each variable has a value of loading factor that represents it. The value of loading factors in EFA can be determined based on the number of samples in the study (Hair et al., 2010, p. 117). The adequacy of the number of observations of data can be identified through the Kaiser-Meyer-Olkin (KMO) parameter with a $\mathrm{KMO}$ value of $>0.5$.

Correlations between multivariate variables can be identified by Bartlett's Test of Sphericity parameter which must have significance with $\mathrm{p}$-value $<0.05$. The magnitude of the correlation between multivariate variables can be seen from the value of Measure of Sampling Adequacy (MSA) with the value of MSA $>0.5$. The value of communal items has acceptable limits which are above 0.30 (Mooi \& Sarstedt, 2011, p. 212). The results of the correlation test between variables are presented in the output of KMO and Bartlett's Test in Table 1.
Table 1. The KMO and Barlett's test instrument of ASOKA on Try-out I

\begin{tabular}{|c|c|c|}
\hline \multicolumn{3}{|c|}{ KMO and Bartlett's Test } \\
\hline $\begin{array}{l}\text { Kaiser-Meye } \\
\text { Sampling Ac }\end{array}$ & $\begin{array}{l}\text { Olkin Measure of } \\
\text { quacy. }\end{array}$ & 0.868 \\
\hline \multirow{3}{*}{$\begin{array}{l}\text { Bartlett's Test } \\
\text { Sphericity }\end{array}$} & Approx. Chi-Squar & 1525.141 \\
\hline & & 91 \\
\hline & & .000 \\
\hline
\end{tabular}

In Table 1, KMO MSA (Kaiser-MeyerOlkin Measure of Sampling Adequacy) has a value of 0.868 . The MSA KMO value is good since it is greater than $0.5(\mathrm{KMO}>0.50)$. It indicates that all character dimensions have met the adequacy requirements of the number of observations (data). Based on the Bartlett's Test of Sphericity, it is obtained a Chi-Square value of 1525.141 at the degrees of freedom of 91 with the significance of less than 0.001 $(<0.001)$. Based on the Anti-Image correlation (AIC), the item having MSA value which is less than $0.50(<0.50)$ is not found, as shown in Table 2 .

Table 2. Values of AIC

\begin{tabular}{llllll}
\hline \multicolumn{2}{c}{ Spiritual Aspect } & \multicolumn{2}{c}{ Personal Aspect } & \multicolumn{2}{c}{ Social Aspect } \\
\hline S1 & 0.774 & P4 & 0.830 & Sos11 & 0.863 \\
S2 & 0.742 & P5 & 0.845 & Sos12 & 0.915 \\
S3 & 0.867 & P6 & 0.921 & Sos13 & 0.923 \\
& & P7 & 0.889 & Sos14 & 0.916 \\
& & P8 & 0.895 & & \\
& & P9 & 0.877 & & \\
& & P1 & 0.800 & & \\
\hline
\end{tabular}

Table 3. Total Variance Explained Value

\begin{tabular}{ccccccc}
\hline \multirow{2}{*}{ Component } & \multicolumn{3}{c}{ Initial Eigenvalues } & \multicolumn{3}{c}{ Rotation Sums of Squared Loading } \\
\cline { 2 - 6 } & \multicolumn{1}{c}{ Total } & $\begin{array}{c}\text { \% of } \\
\text { Var. }\end{array}$ & $\begin{array}{c}\text { Cum. } \\
\text { \% }\end{array}$ & Total & $\begin{array}{c}\text { \% of } \\
\text { Var. }\end{array}$ & $\begin{array}{c}\text { Cum. } \\
\text { \% }\end{array}$ \\
\hline 1 & 6.510 & 46.541 & 46.541 & 4.172 & 29.700 & 29.799 \\
2 & 2.421 & 17.202 & 63.834 & 3.634 & 25.954 & 55.753 \\
3 & 1.165 & 8.322 & 72.156 & 2.296 & 16.403 & 72.156 \\
4 & .695 & 4.962 & 77.188 & & \\
5 & .571 & 4.079 & 81.197 & & \\
6 & .463 & 3.3 .4 & 84.502 & & \\
7 & .437 & 3.122 & 87.623 & & \\
8 & .377 & 2.692 & 90.315 & & \\
9 & .287 & 2.047 & 92.362 & & \\
19 & .273 & 1.950 & 94.312 & & \\
11 & .256 & 1.830 & 96.143 & & \\
12 & .216 & 1.557 & 97.699 & & \\
13 & .177 & 1.267 & 98.966 & & \\
14 & .145 & 1.034 & 100.000 & & \\
\hline
\end{tabular}




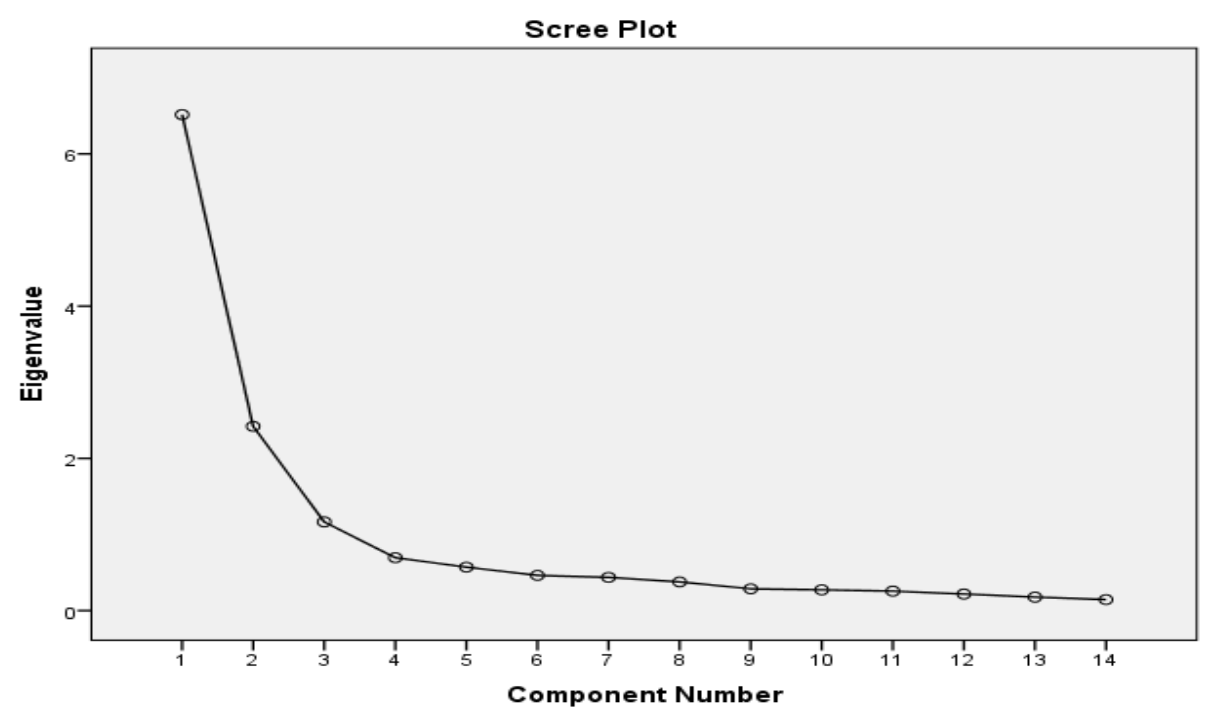

Figure 4. Scree Plot of the ASOKA instrument in the Tryout I

Based on Table 2, no items have MSA value below $0.50(<0.50)$, so that in the next process, all ASOKA instrument items are included. Furthermore, to determine the number of possible factors formed can be seen in the Total Variance Explained table. The Total Variance Explained Value is summarized in Table 3.

In Table 3, Total Variance Explained values can be seen, and the variance that can be explained by factor 1 , factor 2 , and factor 3. The total of these three factors will be able to explain the variable at $72.156 \%$. Thus, because eigenvalues are set 1 , then the total value taken is $>1$, namely components 1,2 , and 3 . In the initial eigenvalues column of the cumulative sub column, it can be seen that the reduction of 14 items analyzed, obtained characteristic values (eigenvalue) as many as three factors. Of the three factors obtained KMO MSA value of 0.868 ( $>0.07$ ), it means fulfilling the requirements to continue. Eigenvalues with values above $1(>1)$ have three factors. It shows that there are three factors in achieving the character of early childhood in TK/ RA according to the estimated indicators. Thus, it can be said that the ASOKA model instrument is said to be valid in terms of the validity of the construct.

The percentage of the loading factor variance that can explain the variance of the early childhood character achievement in TK/ $\mathrm{R} A$ is the first loading factor of $46.541 \%$, the second loading factor of $17.292 \%$, and the third loading factor of $8.322 \%$. Cumulatively, the three factors comprise of $72.156 \%$. Besides, the scree plot which explains the total variance is illustrated in Figure 4.

Figure 4 shows the tendency of Eigen (eigenvalue) decrease used to determine subjectively the number of factors formed. From Figure 4, it can be seen that the scree plot shows the tendency of the Eigen (eigenvalue) decrease indicates that the formed factor leads to three characters dimensions.

\section{Overall Model Fit}

The goodness of the fittest of the measurement model with field data was done using the second-order Confirmatory Factor Analysis (CFA) technique. The second-order CFA analysis aims to determine the validity of indicators developed by the researchers. The existing indicators are said to be valid if the result of the loading factor value is higher than 0.3. The construct validity with the second-order CFA technique is used to test the fitness of the characteristic achievement assessment (Ghozali \& Fuad, 2008, p. 137; Joreskog \& Sorbom, 1999, p. 115). This approach means that the analysis is done directly in two stages, i.e. from the variable to the indicator, then from the indicator to the item. In addition, the second-order CFA also tests whether the data fit with the model that was formed previously or not. 
Based on the standardized second order CFA test output, the statistical values used as the criteria in the good of fit fitness statistics are as follows: $\mathrm{df}=69$; $p$-value of 0.06624 ; Chi-square $(p$-value) $>0.05$; RMSEA value of 0.05 (RMSEA $<0.08$ ), CFI value of 0.99 (CFI $\geq 0.9)$; NFI value $=0.9$; $\mathrm{CFI}$ value $=0.99$; and RMR value $=0.018$. The results of the character measurement model are shown in Table 4.

Table 4 shows the good of the fit test results of the model. Judged from the loading factor value, the indicators are all above 0.3. It indicates that all indicators constructing the authentic assessment components of early childhood characters in $T K / R A$ are valid. The character constructs measurement model has met the goodness of fit statistics so that the character construct measurement model is stated as a good measurement model.

The ASOKA instrument test is done directly, and the SPSS display result shows KMO MSA $>0.05$. Thus, it can be explained that all ASOKA dimensions have fulfilled the requirements of a sufficient amount of observation (data). In addition, Barlett's Test of Sphericity shows the significance of a $p$-value less than 0.05 ( $p$-value $<0.05)$, indicating a significant correlation between observed variables of all dimensions. It can be concluded that the data of observations of character dimensions of TK/RA students have been qualified for the confirmatory factor analysis.

The overall model goodness of fit evaluation of each character dimension based on the second-order CFA ( $2^{\text {nd }} \mathrm{CFA}$ ) test shows the fitness of the model with the data. The main criterion of the model matches with the field data if at least three requirements of seven commonly used measures are fulfilled, namely (1) Chi-square ( $p$-value), (2) Goodness of Fit Index (GFI), and (3) Root Mean Square Error of Approximation (RMSEA). The model is said to be fit if Chi-square has a significance level $(p$-value) $\geq 0.005$; Goodness of Fit Index $(\mathrm{GFI}) \geq 0.90$; and Root Mean Square Error of Approximation (RMSEA) is $0.05<$ RMSEA $\leq 0.08$ (Browne \& Cudeck, 1993). Thus, it can be interpreted that the indicators specified to measure each dimension (personal, personal, social) together measure things accordingly. It is further seen that all sizes of GOF (goodness of fit) show a good model matching with the field data, so it can be concluded that overall, the ASOKA model on all character dimensions is fit.

An instrument for assessing students' character had been developed and proved to be valid and reliable, and then the feasibility of the model was tested by trying it out based on the model usage guideline. The ASOKA model usage guideline is in the form of a handbook completed with the assessment instruments and procedures as well as guidelines on writing the assessment reports. This handbook was tested to 15 teachers/potential users from $15 T K / R A$ in Yogyakarta.

\section{Discussion}

In developing this character assessment model, the researchers adopt Plomp's (1997, p. 5) approach that is modified into four phases: (1) the initial investigation stage, (2) design, (3) prototype construction, and (4) development. This development process produced a construction of the ASOKA model consisting of three aspects, namely: the spiritual aspect, the personal aspect, and the social aspect. The spiritual aspect consists of three characters: (1) faithfulness, (2) worshipping ritual (bablum minallab), and (3) humanity

Table 4. Goodness of fit test results of ASOKA model on Tryout I

\begin{tabular}{ccccc}
\hline No & GOF Effect Size & Fitness Level Target & Estimated Value & Fitness Level \\
\hline 1. & Chi-square $\left(\mathrm{X}^{2}\right)$ & $<2 \mathrm{df}$ & 87.44 & good fit \\
2. & p-value & $>0.05$ & 0.06 & good fit \\
3. & RMSEA & $\leq 0.05$ & 0.05 & good fit \\
4. & NFI & $\geq 0.90$ & 0.96 & good fit \\
5. & NNFI & $\geq 0.90$ & 0.99 & good fit \\
6. & CFI & $\geq 0.92$ & 0.99 & good fit \\
7. & RMR & $<0.05$ & 0.018 & good fit \\
\hline
\end{tabular}


(bablum minannas). The personal aspect consists of six characters, namely: (1) honesty, (2) patience and modesty, (3) bravery and confidence, (4) self-discipline, (5) creativity, and (6) self-independence. The social aspect consists of five characters: (1) caring/empathy, (2) tolerance, (3) responsibility, (4) cooperation, and (5) politeness and humbleness. These characters are the results of the development of the assessment model in its early stages to assess the character development of young learners in $T K / R A$.

The method used in the ASOKA assessment model was an authentic assessment employing observations. It is in accordance with Meisels, Bickel, Nicholson, Xue, and Atkins-Burnett (2001, p. 75) who assert that the appropriate method for assessing kindergarten children is through performance inherent in the curriculum or often referred to as an authentic assessment. The assessment was done gradually and continuously so that the progress towards children's character development can be measured. In line with this fact, Suyanto (2005, p. 189) has suggested that an assessment is done through real, function$\mathrm{al}$, and natural activities starting from the time the students get to school until they go home. The observation method employed in this assessment model has also been appropriate, as Azwar (2015, p. 90) states the assessment of attitudes (characters) can be done through behavioral observations. When a child shows repeated or consistent behaviors, it can be said that they already have those behaviors as their characters. A child's behaviors that appear repeatedly (consistently) show that the child has characters. For example, there is a child who always prays before doing any activities such as eating, drinking, and even playing; then it can be said that the child has a spiritual character. It is said so because when the child always prays before doing anything, he/she shows his/her belief in the existence of God/Allah.

In addition, validity was proven and the reliability of the ASOKA model instruments was estimated. The content validity of the instrument was obtained from expert judgment through the Delphi method and continued with analysis using the Aiken's formula.
Based on the analysis, the overall results of the instruments' indicators and items had Aikens index from 0.714 to 1.000 , meaning that the proposed indicators and items were valid. The criterion which was used to determine the validity level was that of Retnawati (2016): Aikens's agreement index of 0.4-0.8 shows medium validity; an index of more than 0.8 shows high validity. In conclusion, all of the proposed indicators can be used to develop an authentic assessment instrument to assess the characters of young learners in TK/ $\mathrm{R} A$. The Aiken index is chosen because it is considered accurate to measure the content validity of an instrument. The instrument is valid if it measures what it should measure based on the raters' agreement.

The construct validity is the result of testing relating to the scale level that reflects and acts like the concept being measured (Hair et al., 2010, p. 710). The analysis of construct validity to character dimensions was performed by using Exploratory Factor Analysis (EFA). This analysis resulted in KMO value of $0.868(\mathrm{KMO}>0.50)$; Chi-Square of 1525.141 with 91 degrees of freedom and significance less than $0.001(<0.001)$; Anti Image Correlation (AIC) values of more than 0.50 (AIC > 0.50); communality value of 0.611 0.791 (communality $>0.03$ ) which already fulfills the prerequisite criteria (Mooi \& Sarstedt, 2011, p. 212).

Meanwhile, the instrument reliability was calculated by using Cronbach's Alpha approach. The Cronbach's Alpha coefficient for the reliability of the ASOKA model was 0.914 . This value is higher than $0.70(>0.70)$. This requirement refers to instrument reliability criteria (Mardapi, 2017; Nunnally, 1981, p. 115) which state that an instrument is considered reliable if the alpha reliability is 0.70 or higher. ASOKA model instrument's validity and reliability have been estimated and the results show that this instrument is valid and reliable. The assessment instrument product obtained is then used to assess the achievement of early childhood character development in TK/RA. This assessment is in the form of a checklist containing character assessment indicators including 14 characters described in 65 assessment items. 
An authentic assessment model to assess kindergarten... Umi Faizah, Darmiyati Zuchdi, \& Yasir Alsamiri

Further product development in this study is a user manual of the ASOKA model. It serves as a guide for the users, that is, kindergarten teachers, in applying the ASOKA instruments. The results of the assessment are used as the basis for the feasibility of using the ASOKA model in TK/RA. Assessment results from $T K / R A$ teachers show that $72 \%$ assume that this model is good, meaning that it can be used without any revision. Fourteen percent thought that the manual is good enough, meaning it could be used with little improvement, while the other 14\% would judge that the manual is excellent, ideal to be used as an example for character assessment.

Some weaknesses in ASOKA's user manual have been improved. It is done to improve the quality of the function of the ASOKA model as a valid and reliable assessment model that is able to measure the achievement of early childhood character in $T K / R A$. The use of this ASOKA model is started from the making of the RPPH (Daily Learning Program Plan) and ended by assessing the expected characters. Thus, all the points of behavior that become indicators of the achievement of the child's character can be appraised properly.

In assessing the achievement of the children's characters, it is necessary to diversify the system and the method of the assessment because the use of a varied method will better guarantee the quality of the assessment result. Thus, the construct of the ASOKA model developed by the researchers is one of the important assessment models used to help facilitate $T K / R A$ teachers in performing their duty to do the assessment, which is inseparable from their two other tasks namely planning and conducting the learning process effectively.

After passing the experiment with a wide sample, the results of the ASOKA model development fulfill the validity and reliability criteria and it is also considered as the correct measurement model because it fulfills the criteria of goodness-of-fit model. Thus it can be stated that the developed instrument has a feasibility standard as an instrument to detect the level of achievement of early childhood character in $T K / R A$.

\section{Conclusion}

Based on the findings and discussion, the conclusion of this study can be formulated as follows. (1) ASOKA is an authentic assessment model developed to assess the achievement of early childhood character in TK/RA. This model consists of an instrument and manual of the assessment model to assess the character of early childhood in TK/ RA. The ASOKA model is effective because all the indicators used to measure the spiritual, personal, and social aspects of early childhood character constructs in TK/RA mostly have a loading factor value greater than 0.30 , while the reliability of the character constructs is proved from the value of the construct reliability coefficient $(\mathrm{CR})>0.70$, i.e. $\mathrm{CR}=0.72$ on the spiritual aspect; $\mathrm{CR}=0.79$ on the personal aspect; $\mathrm{CR}=0.86$ on the social aspect. The ASOKA model also meets the criteria of the goodness-of-fit statistic, so the ASOKA model is considered as an assessment model that can be used to detect the achievement of early childhood character in TK/RA. (2) The characteristics of the authentic assessment model instruments to assess early childhood character outcomes in TK/RA are as follows: (a) the content validity of the ASOKA (Authentic Character Assessment) instrument is high. Based on the results of Formula Aiken's $\mathrm{V}$ analysis, the overall results of the indicators have an Aiken index of 0.714 to 1.000 , the average index is 0.901 ; (b) The validity of the ASOKA model instrument construct (Authentic Assessment for Character) using the second-order CFA approach was obtained by a fit model to assess the character of early childhood in TK/RA. It means that the developed model of ASOKA meets the criteria of goodness-of-fit statistics; (c) the reliability of the developed instrument is high with the Cronbach Alpha value coefficient 0.914.

\section{References}

Abidin, M. Z. (2012). Tingkat pendidikan di Indonesia. Seminar Pendidikan Karakter. Bali: Universitas Udayana.

Arends, R. I. (1997). Classroom instruction and management. New York, NY: McGrawHill. 
Ash-Shiddieqy, T. M. H. (2009). Sejarah dan pengantar ilmu Hadits. Semarang: Pustaka Rizki Putra.

Azwar, S. (2015). Skala pengukuran sikap manusia. Yogyakarta: Pustaka Pelajar.

Bar-On, Reuven. (2000). Emotional and social intelligence: Insights from the emotional quotient inventory. In $\mathrm{R}$. Bar-On \& J. D. A. Parker (Eds.), The handbook of emotional intelligence: Theory, development, assessment, and application at home, school, and in the workplace (pp. 363388). San Francisco, CA: Jossey-Bass.

Bar-On, Reuven. (2005). The impact of emotional intelligence on subjective well-being. Perspectives in Education, 23(2), 1-22. Retrieved from https:// hdl.handle.net/10520/EJC87316

Browne, M. W., \& Cudeck, R. (1993). Alternative way of assessing model fit. In K. A. Bollen \& J. S. Long (Eds.), Testing Structural Equation Model. New York, NY: SAGE Publication.

Edgington, M. (2004). The foundation stage teacher in action: Teaching 3, 4, and 5 years olds. London: PCP Press.

Gardner, H. (1996). Intelligence: Multiple perspectives. Fort Worth, TX: Harcourt Brace College.

Ghozali, I., \& Fuad, F. (2008). Structural: equation modeling. Semarang: UNDIP Press.

Hair, J. F., Black, W. C., Babin, B. J., \& Anderson, R. E. (2010). Multivariate data analysis (7th ed.). Upper Saddle River, NJ: Prentice Hall.

Hamruni, H. (2009). Strategi dan model-model pembelajaran aktif menyenangkan. Yogyakarta: Fakultas Tarbiyah UIN Sunan Kalijaga.

Herman, J. L., Aschbacher, P. R., \& Winters, L. (1992). A practical guide to alternative assessment. Alexandria, VA: Association for Supervision and Curriculum Development.
Jamaris, M. (2004). Assesmen pendidikan anak usia dini. Seminar Dan Lokakarya Nasional Pendidikan Anak Usia Dini. Jakarta.

Joreskog, K. G., \& Sorbom, D. (1999). Lisrel 8: User's reference guide. Chicago, IL: Scientific Software International.

Law of Republic of Indonesia No. 20 of 2003 on National Education System. , (2003).

Lickona, T. (1991). Educating for character: How our schools can teach respect and responsibility. New York, NY: State University of New York.

Lickona, T. (2004). Character matters: How to belp our children develop good judgment, integrity, and other essential virtues. New York, NY: Simon \& Schuster.

Louster, P. (2002). Tes kepribadian (C. G. Sumeksto, trans.). Yogyakarta: Kanisius.

Majid, A., \& Andayani, D. (2011). Pendidikan karakter perspektif Islam. Bandung: Remaja Rosdakarya.

Mardapi, D. (2017). Pengukuran, penilaian, dan evaluasi pendidikan (2nd ed.). Yogyakarta: Parama Publishing.

Marzuki, M. (2015). Pendidikan karakter Islam. Jakarta: Amzah.

Meisels, S. J., Bickel, D. D., Nicholson, J., Xue, Y., \& Atkins-Burnett, S. (2001). Trusting teachers' judgments: A validity study of a curriculum-embedded performance assessment in kindergarten to grade 3. American Educational Research Journal, 38(1), 73-95. https://doi.org/ 10.3102/00028312038001073

Miskawaih, A. A. A. I. (1994). Menuju kesempurnaan akblak (H. Hidayat \& E. Hasan, trans.). Bandung: Mizan.

Mooi, E., \& Sarstedt, M. (2011). A concise guide to market research. Berlin: Springer-Verlag Berlin Heidelberg.

Munawar-Rachman, B. (Ed.). (2015). Pendidikan karakter: Pendidikan mengbidupkan nilai untuk pesantren, madrasah dan sekolah. Jakarta: LSAF dan ALIVE Indonesia. 
Munawwir, A. W. (1997). Kamus Arab-Indonesia (14th ed.). Surabaya: Pustaka Progressif.

Naim, N. (2012). Character building: Optimalisasi peran pendidikan dalam pengembangan ilmu dan pembentukan karakter bangsa. Yogyakarta: Ar-Ruzz Media.

Nunnally, J. C. (1981). Psychometric theory. New York, NY: Mc-Graw Hill.

O'Malley, J. M., \& Pierce, L. V. (1996). Authentic assessment for English language learning: Practical approaches for teachers. New York, NY: Addison-Wesley.

Plomp, T. (1997). Educational design research: An introduction. In T. Plomp \& N. Nieveen (Eds.), Educational design research. Enschede: Faculty of Educational Science and Technology, University of Twente.

Popham, W. J. (1995). Classroom assessment: What teachers need to know. Boston, MA: Allyn and Bacon.

Retnawati, H. (2016). Proving content validity of self-regulated learning scale (The comparison of Aiken index and expanded Gregory index). REiD (Research and Evaluation in Education), 2(2), 155-164. https://doi.org/ 10.21831/reid.v2i2.11029

Schiller, P., \& Bryant, T. (2012). 16 moral dasar bagi anak (S. Sensusi, trans.). Jakarta: PT Elex Media Komputindo.
Schopenhauer, A. (1997). Menembus selubung sang maya. In F. M. Suseno (Ed.), 13 Model pendekatan etika. Yogyakarta: Kanisius.

Semiawan, C. R. (Ed.). (2008). Penerapan pembelajaran pada anak. Jakarta: Indeks.

Stiggins, R. J. (1991). Relevant classroom assessment training for teachers. Educational Measurement: Issues and Practice, 10(1), 7-12. https://doi.org/ 10.1111/j.1745-3992.1991.tb00171.x

Suyadi, S. (2013). Strategi pembelajaran pendidikan karakter. Bandung: Remaja Rosdakarya.

Suyanto, S. (2005). Konsep dasar pendidikan anak usia dini. Jakarta: Departemen Pendidikan Nasional.

Thorndike, R. L., Hagen, E. P., \& Sattler, J. M. (1986). Stanford-Binet intelligence scale (4th ed.). Chicago, IL: Riverside.

Zaenul, A. (2001). Alternative assessment. Jakarta: Direktorat Jenderal Pendidikan Tinggi, Departemen Pendidikan Nasional.

Zuchdi, D. (2006). Pendidikan karakter melalui pengembangan keterampilan hidup (life skills development) dalam kurikulum persekolahan. In Laporan penelitian hibah pascasarjana. Yogyakarta. 